\title{
GENESIS OF ECONOMIC CULTURE FORMATION
}

\author{
Abdukhakim Mamanazarov \\ $\mathrm{PhD}$, Tashkent Branch of M. V. Lomonosov Moscow State University, \\ e-mail: abduhakim_bazarovich@mail.ru, orcid.org/0000-0002-4253-7629, Uzbekistan \\ Maria Manuela Tavares Ribeiro \\ $\mathrm{PhD}$, University of Coimbra, \\ e-mail: mtribeiro7@gmail.com, orcid.org/ 0000-0001-7471-2164, Portugal
}

Paul Allies

Prof., University of Montpellier, e-mail: paul.allies@umontpellier.fr, France

Volodymyr Kulishov

Prof., DSc, Kryvyi Rih Economic Institute of Kyiv National Economic University named after Vadym Hetman, e-mail: kulishov_vv@kneu.dp.ua, orcid.org/0000-0002-8527-9746, Ukraine

Abstract. The article investigates modern concepts and theories of economic culture formation, the culture development processes of society and economic culture models taking into account national, business, and cultural traditions. Moreover, various points of view regarding the essence of economic culture presence in the terms of economic globalization are pointed and on the macro and micro levels some positive stages of economic culture formation on the society development modern step are outlined.

Keywords: economy, culture, economic culture, globalization, macroeconomic level, microeconomic level, economic relations, economic system, consumption culture, saving culture.

DOI: http://dx.doi.org/10.23856/2402

\section{Introduction}

In the terms of passing to innovation economy the meaning of culture increases greatly, whereas its high level represents the economic growth factor, it dictates new models of economic behavior and raises new demands. Economic agents are required to possess new level of demand culture, consumption culture and economic interrelation culture that defines the content of modern economic culture as a whole. The main aim of economic culture is to unite disparate, as it would seem, notions: morality and commerciality, severe rules of competitive struggle and business ethics of active participants in market interrelations.

In the society fundamental economic transformations are constantly taking place. They are followed by the mutually influencing each other's processes in economic relations and economic consciousness of people compiling together common direction of modern society economic culture development (Krynski, Campechano Covarrubias, Mamanazarov, Kulishov, 2016).

The economic culture is a powerful factor for economic renovation of the society. This is precisely why economic culture draws more and more attention of different schools social scientists as sociologists, cult urologists, economists, psychologists, and educationalists.

The economic transformations from all the citizens and first of all from future specialists require entering upon new economic knowledge which would allow to perceive 
arising changes sensibly. Society democratization, fundamental basis change in publiceconomic structure and in management forms requires forming new cultural values.

The culture of each people is diverse. There exists only its identical management mode and the ways of economic business control. However, the globalization characterizes the culture as an international business. The existence of economic field international organizations proofs the fact that the economic culture is becoming more united though it is powered from various national sources, mentality, and the ways of thinking. In the terms of globalization and transnationalization there appear integrative cooperation of cultures and their biding (Cimeno Sacristan, 2001). In these circumstances the formation of new economic thinking becomes a society social order. On one hand, it presupposes clear view concerning the market system essence, perceiving its development laws. And, on the other hand, on its basis it is the search of the formation ways of adequate type of economic thinking and conduct standard, representing modern level of economic culture becoming one of the main factors of the growth national economics (Eagleton, 2001).

The economic culture is one of the most specific culture fields and it is connected with the reproduction of the relations formed between people in the process of communication and concerning their household activity. This type of culture represents a sort of representation of economy on the sphere of culture. Though, the opposite statement is also correct, according to which culture is a representation on to the sphere of economy. An economic component of culture influences the whole "culture field" of a certain society (including science, art, religion), reflecting directly in those culture spheres that are mostly connected with economic one (as juridical and political cultures). The economic culture becomes an integral component of economic processes as it expresses the ideas and ambitions of their individuals and facilitates the consolidation and mutual activity of the latter one. It appears to be the most important characteristics and synthetical index of the whole society economic development (Mamanazarov, Gushko, Kulishov, 2016).

In the function process the economic culture reveals special features of a social life. Furthermore, it reflects stable forms of economic conscious determining the character and the direction of economic development. It actively influences the condition and the level of human development as well as the formation his/her economic positions and the form of participation in economic social life considering that it develops the system of economic values and fundamental norms of economic behavior.

\section{Historical and economic community of economic culture}

Underdevelopment of culture complicates valuable realization of main economic functions. From the side of solution of appeared contradictions economic culture can be interpreted as the way of interaction between economic conscious (as the reflection of economic relations and functioning cognition, and economic laws development) and economic thinking (as the reflection of involving into economic activity) regulating the participation of employable and unemployable social groups in economic activity as well as the degree of their self-actualization in any particular types of economic behavior. The more advanced the way of its interaction is, the more effective economic activity of business entity will be (Bauman, 2002).

The economic culture, as a regulator of economic conscious and economic thinking connection, is oriented to the regulation of peoples' economic behavior with the aim of raising material welfare more than any other. 
The values of economic culture being a part of common system of humanistic values make the basis of its humanitarian culture (ethic, ecological, aesthetical, labor, and so on.) Perspectives in upbringing humanization possessing the meaning of providing person's conscious choice of social values and formation on their basis stable individual humanistic value system is mainly depend on integration these values into pedagogical process as an example (OCDE/INITE, 2008).

Moreover, the economic culture presupposes formation of certain moral and business personal characters that are important in future labor activity: social activity, entrepreneurial spirit, initiative, business and cautious treatment toward public possessions, organizational skills, reliability, striving for profitability, technological process renovation, personal success, and welfare.

In accordance with macro and micro levels of economy it is suggested to differentiate culture as well. Beside the general culture there exists particular culture that is micro level culture. First of all, from this level culture is formed. To form economic culture in people with the help of various ways above all it is needed to identify what the culture is and what it includes. To begin with, from this point of view the most important task is to define the essence of particular category.

In modern scientific literature the economic culture formation is considered from philosophical, social, psychological, culturological and pedagogical points of view as the given category is interdisciplinary.

The presence of near-border categories in various humanitarian sciences is defined by the fact that there is no pure phenomenon in modern civilization. It inosculates with other phenomena and exists under their active influence. For instance, pure economical approach toward the research in economy is implemented nowhere, but at the same time economic analysis methods are used in other social sciences. In the context of this while considering economic culture it is essential to emphasize first of all its economic part.

In the past the economic culture was considered as the behavior of economic person. A. Smith, M. Veber, A. Marshal, A. Nord, J. Shumpeter and other representatives of classical liberalism abided that definition. Neoliberalism and institutionalism include the notion of culture and social aspects of economic activity. Modern economists do not make enough research in the sphere of revealing culture content considering it as a philosophical category. Particularly economic culture is a near-border category of social sciences but it has rich economic content. However, many economists restrict it to the religious origin of economic activity and value it from the general understanding of morality, notably they narrow it down to the feelings of responsibility, complacency, fear, insult and guilt. Absolutely, there is an ethical basis in culture forasmuch as a human being is culture bearer and behaves oneself according to its norms. But, this does not give any reason for underestimation of economic essence of culture. However, the evaluation of culture as the notion of "measures and ways of human's power realization" is met in literature. According to the authors, economic culture is the system of meanings and traditions in economic sphere and the product of economic relations in the society. The economic culture depends on these relationships. It is economic entities' behavior which is based on the conditions of objective factors. The process of economic culture formation is objective, but, its bearers are certain entities that can act in economy on their own way. In accordance with economic laws in the modern characterization of economic culture the subjectivistic basis dominates that reflects people's behavior. But, this is subjective reflection of objective, i.e. economic realias that each entity of economy can come across with without any exceptions. Every person perceives objectivity in his own way 
and makes his own decision, appeals his own actions. In connection with this fact while interpreting economic culture it is impossible to lose sight of objective determiners of culture behavior. The person individually joins in economic relationships but he has to contend with economic realias that do not allow him to make random economic actions. The person cannot ignore the laws of economy that are objective, but he can get used to law requirements if he has enough economic knowledge and practical experience. That kind of personal skill does not afford ground for especial subjectivistic interpretation of economic culture. Based on everything mentioned above, it is possible to conclude that economic culture is economic entities' behavior conditioned by its laws and rules.

The culture of separate people and the group of people depends on their socioeconomic situation. Mental basis is a subculture derived from general culture and characterizes national feature in economic culture. For example, at all times in Uzbekistan there exists cooperative fulfillment of public work, preferences in land share-leasing, tendency to private small-scale farming management, private family business, household labor, day-wage work engagement, striving for demonstrative affect of personal consumption and achieving personal image of economy in the resources consumption by the members of a big family, retrained in consumption, frequency in benefit collective consumption, tendency to the savings with the aim of heritage for children, conducting festivities and ceremonies.

A Culture compound is the norm of economic behavior expressing the norm of economic activity of economic actions. Considering that culture is determined by economic laws regulating the economic striving and activity boundaries it preserves all the main features of generic notion of culture defining the extent of personal skills concerning controlling the circumstances of his existence. At the same time economic culture represents a unique specific form and a view of general culture. However, it depends on nature influence and economic system laws and it defines the unique content of valuable guides of economic actions (Bruner, 1990).

In culture there is a historical moment connected with economic structure change and that is why during its evaluation it is essential to take into consideration modern economic traits. Culture being as economic system product contains general and specific basis. Generality is determined by continuity of economic systems, when in the process of transformation of one system into another, new system inherits those culture elements that could live together with new system, adapts to new requirements.

Combination of elements of various systems forms historical community of economic culture (Pelaez, 1984). Natural conditions as people's genuine habitat affect people's economic behavior. Whereas, as a nature product habitat is conservative notable in the conditions of market economy functioning. Vitality is defined by laborious share-leasing in land-poor conditions. But, this is an effective way of laborious farm managing as renter's profit is straightly geared to the productivity.

Also, natural factor affects the consumption culture and people's consumption varies depending on hot, cold, and moderate climate types. Moreover, it dints in labor culture. Favorable natural conditions make the rise of individual labor effectiveness possible, but unfavorable conditions demand co-operative labor efforts. Due to this, from ancient times in Uzbekistan there exists "Hashar" tradition, cooperative labor, mutual help in labor that turned to be labor culture feature and it was constantly repeated. Scheduled system, when nationwide "Hashar" called "Communistic subbotnik" was not an exception. Hashar is a traditional culture element in Uzbekistan because it became an integral part in labor culture. 
Modern culture imbibes own interest achievements and neoliberalism representatives emphasize it.

As M. Fridman claims, valuable mark for a company can only be a profit guarantee; business cannot be oriented on social values. However, complementary evaluation of economic culture, that excludes uncompromising struggle for the sake of person's egoistic aims and particularly rational economic action, gains its momentum.

It is stipulated by the fact that people cannot change these principals at their own discretion; they can only adapt their behavior to these principles. That forms the basis for economic culture. It is known that market economy always consists of two blocks, namely: open one - clear, and closed one- shady. Economic culture is attributable to the first block. As for the relations within the shady sector of economy, it is not civilized, therefore, it does not form the modern economic culture; though, it actually functions in the majority of countries.

The modern economic culture generates not only the market rules of behavior, although they are dominant, but also non-market behavior, which is being the product of transformation of purely market economy into the mixed one. Non-market relations are humanitarian and based on mutual help and support principle. However, these principles do not exist everywhere, they are present in the distribution sphere where non-market revenues are formed and represented as an aid to poor countries and citizens, charity or social pensions and benefits.

Since the economic relations are diverse and the economic culture has a multilayer inner structure, which has various definitions, the approach to the analysis of the economic culture components may vary:

- in respect of common and mental culture;

- from the point of view culture bearer- an individual, mini-, macrogroups and society as a whole;

- from the point of view of functional activity.

The first two approaches are important from the cognitive point of view, but it lacks productivity in practice. The third approach is important from the practical point of view as it allows to detect the cultural degree in a particular sphere of human activity and to determine the measures of development in a particular direction. In the modern conditions of formation and growth of market economy of young states, the third approach to economic culture studying is the most useful one.

Culture as a product of economic system change is followed by the change of value orientations, while the mentality remains unchanged. It has traditional basis. It is commonly known that repeatedly occurring events become a tradition. Traditional cultural features can remain even when economic relations change, provided that they are modernized and adapt to new economic conditions and serve new aims.

\section{Components of economic culture}

Intracorporate relations stand out on the foreground in multi-tiered system of relations as here a creation of market production and services occurs here. These relations are primary, and they are microeconomic structure. The culture of intra-entrepreneurial relations shows the accurate coordination of actions of separate workers and group of workers between themselves for the sake of achievement of an ultimate goal - high profitability, i.e. efficiency of work. It assumes a certain measure of the interaction, defined by a culture of behaviour of participants of manufacture. In the social plan the intracorporate culture demands social 
partnership of proprietors, managers as well as hired workers and appears one of the economic culture components.

This is the only way to make it possible to provide harmony of interests and to avoid internal social conflicts that acts as an invariable condition of competitiveness as it reaches high quality of production at the least expenses for its manufacture. But it does not mean disappearance of conflicts. The coordination of interests can be replaced by their infringement that generates conflicts and consequently the culture of intracompany relationships should be accurate that they could quickly and operatively settle conflicts to the least losses for collective and conflicting parties. The higher level of relations within the company, the higher corporate patriotism it has, hence, the competitiveness of collective increases. Behaviour standarts of workers are regulated by the written laws and unwritten traditional rules which pass from one generation of workers to another, i.e., are reproduced in time, but replenish with new rules, i.e. the development of corporative and intercorporative relations.

Corporative relations assume income generation of activity according to distribution laws that is fixed in certain rules which create a culture of work and earnings.

The culture of labor and earnings is a part of economic culture as well. The labor culture is a diligent performance of the official duties irrespective of character and the position status. As it is supported by employees of all categories. Its requirement is an effective work of each employee in his place with strict observance of labor discipline. The labor culture assumes the co-ordinated and high-efficiency work for the sake of own interests and interests of labour collective, observance of all rules of labour behaviour, construction of labour relations according to internal rules and the legislation on work. The labor culture and labour earnings are uniform in the basis as work is always the earnings source. The main thing in a culture of work is conformity of earnings to requirements of the market law of the distribution providing conformity of monetary incomes to a labour efficiency level. This law is objective, and the culture of incomes develops not contrary to it, but according to it. People possess various resources and use them differently, obtain various incomes, which are accurately fixed in culture. The culture of earning money conforms to justice principles, i.e., incomes should be earned, in other words profits should be result of voluntary work, free employment and an alternative choice.

The economy is based on business and consequently its culture is a part of economic culture. Culture of business - is a behavioral actions of businessmen in the market for the purpose of minimisation of expenses and profit maximisation. It includes, firstly, the culture of work on the market. The culture of work on the market is the ability to adapt the requirements of market laws and finding ways of an alternative choice of effective activity.

Secondly, the culture of mutual relations with partners. In business except culture of a competition there is also a culture of partner relations arising at a generality of financial interests. This culture demands benevolence, mutual understanding and respect of mutual interests as well.

Thirdly, the culture of competition. There are not only contradictions of interests in the market, but also points of their contact; it generates economic responsibility of each subject before the partner. Responsibility means strict fulfillment of the obligations to others. It is impossible to provide own interests, not to reckon with interests of partners.

Fourthly, culture of mutual relations with the state. The culture of business is inconceivable without an establishment of civilised relations with the state which is represented not only the power, but also the important agent of market economy. The culture of relations with the state demands performance of obligations to the state, business dealing 
according to requirements of economic policy of authority, inclusion in regulating activity of the state, fair and timely performance of state orders without drawing of a damage to interests of the state, observance of requirements of laws and orders of the authorities, target use state preference.

In modern civilized economy, the cultural factor acts as force of streamlining of economy, means avoidance of chaos in it. The economic culture, accurately dividing the permitted and unlawful, defines borders of economic freedom, standards of an economic life thereby provides realization of cash economic potential and economic safety of a society.

The important link of business culture is self-regulation of own activity, using market mechanisms. Regulation of the economy includes, on the one hand, market self-regulation, and on the other hand - state regulation. As the main regulator acts the market mechanism which represents a set of interdependent and co-operating economic levers are the finance, the prices, benefit, profit, losses, bankruptcy, percent, economic sanctions, a competition, unemployment etc.

In these levers force of provision of economic incentives and even compulsion of participants of business to activity is covered. The market mechanism connects together economic interest and responsibility. Each subject of business cannot reach own interests, not being considered with the obligations to others. Interests of each subject are egoistic, but the market realises them differently.

In economic culture the special place is occupied by the culture of consumption. Consumer culture is the conventional rules, standards and models of consumption of financial and spiritual benefits the value of which is the maximization of satisfaction of needs at a given level of income. It is particularly expressed in culture of a consumer choice and in character of the consumption, but with the account of consumer ability of various people. The culture of consumption of rich people, people of an average prosperity and poor is allocated. But irrespective of it people are guided by the general beginning of consumption, but in various degrees.

In the general typology of consumer behavior it is possible to allocate three groups of the consumers which cultural propensities differ:

- Reasonably consuming;

- ascetics;

- hedonists.

Despite it there are general stereotypes of culture - orientation to satisfaction of reasonable requirements. Consumption types exist at superiority of one them. At underdeveloped economy dominating is - hedonism, and at developed - rationality. Asceticism as neglect financial benefits is very seldom.

The consumer culture is a culture of a consumer choice, i.e. norms and action rules in the consumer market. It requires that the consumer regards with the realities of the market, namely degree of a saturation of the market the goods and a price level on them. The cultural consumer makes a choice between quality of the goods and the prices that provides consumption rationality. The culture of consumption is guided by such value, as a healthy lifestyle and life expectancy. Thereby it excludes consumption of socially harmful goods, but provides consumption of the goods shortening a life, saving time of consumption and providing not only physical, but also intellectual developments of the person. An integral part of the culture of consumption is the art of protecting consumer rights provided for by laws. It means, firstly, ability to find out infringement of own consumer right, secondly, ability of protection of the rights. 
The element of the general economic culture is the culture of savings. It means financial behavior of people in formation and expedient use of own savings. The higher the propensity is to save, the higher the culture is.

The culture of behavior demands not only the big propensity to savings, but also their uses with advantage for itself and for a society that is reached by their capitalizations, i.e. transformation into the capital bringing the income and it is reached by an alternative choice between profitableness, risk and safety of financial investments. The culture of savings means freedom of savings activity in any situation as well as at any scales. However, this freedom should serve interests not only savers, but also other groups of people and a society as a whole to which stability of the financial reference and comprehensible rates of growth of inflation is necessary. It is possible to measure the level of savings culture not only by growth of propensity to savings, but also as they are put in business. The financial remainder as the form of savings is an indicator of low culture, however, using it the level of culture can be characterized. If the growth of household financial resources indicates a decline in culture, then reducing it and increasing financial investment in the case, on the contrary, shows an increase in culture. The culture of savings is a regulator of savings activity. Growth or decline in people's savings significantly affects the movement of investment flows, the growth of which, as is known, is a factor in the dynamic development of the economy.

\section{Conclusions}

The economic culture is a category which has economic, social, pedagogical and psychological aspects, has intermediate character, moreover is a part of the general culture, and represents the relations between people, assuming observance of norms and behavior rules.

In a multy-vector structure of culture the economic culture as the economy is the main sphere of human activity dominates. The economic culture is an economic behavior of all subjects of the economy, objectively defined by the necessity following from laws and rules of economy. Culture is a subjective perception of the objective. Objective - this is a real economic relationship that exists against the will and desire of people. But people can learn their laws and secrets and consciously operate for the sake of their own interests.

Economic relations are an object of culture, and a person is its subject, that is, a carrier, and therefore each in its own way recognizes the objective and builds its actions on them.

By virtue of this there is various a level of culture of separate people, groups of people and a society as a whole. Due to the continuity of the economy, the presence in it of common principles, regardless of the nature of the economic system, determines the commonality of economic culture. Because it is a product of historical development, it has common and mental features that are expressed in cultural traditions, transmitted from generation to generation, but modernized under the influence of economic systems.

National-specific in culture as a mentality, always exists, but within a common culture.

The economic culture is a competence of the person of acceptance of economic decisions and their realisation in practice for the purpose of achievement of economic interests. Such ability is formed by supervision over actions of other people, perception and use of another's experience. But this way is long; it takes a lot of time and involves great costs. An effective way to achieve a high culture involves combining the accumulated experience with deep economic knowledge. Knowledge forms rational thinking and practical actions. 


\section{References}

Bauman, Z. (2002). La cultura como praxis. (Ed.). Espana: Paidôs. [in Spanish].

Bauman, Z. (2009). La globalizaciôn. Consecuencias humanas. (Ed.). México: Fondo de Cultura Econômica. [in Spanish].

Bauman, Z. (2011). Danescolaterab, Desigualdades sociales en la era global. (Ed.). México: Fondo de Cultura Economica. [in Spanish].

Bruner, J. (1990). La educacion, puerta de la cultura. (Ed.). Madrid: Visor. [in Spanish].

Burunova, O., Gushko, S., Kulishov, V. (2016). Knowledge Economy In The System Of Continuous Education Of Ukraine: Society. Integration. Education. Proceedings of the International Scientific Conference 1:67. [in English].

Cimeno Sacristan, J. (2001). Educar y convivir cultura global. (Ed.). Madrid: Morata. [in Spanish].

Covarrubias, C. J. (2014). El modelo educativodel snte: Formar y Profesionalizar para el Sigh 21. Mexico: La Editorial del Magisterio «Benito Juarez» del SNTE: 96. [in Spanish].

Dimaggio, P. (1994). Culture and Economy. The Handbook of Economic Sociology. (N. J. Smelser \& R. Swedberg, Eds.). Princeton, 27-57. [in English].

Eagleton, T. (2001). La idea de cultura Un politica sobre los conflictos culturales. (Ed.). Espana: Paidos. [in Spanish].

Krynski, A., Campechano Covarrubias, J., Mamanazarov, A., Kulishov, V. (2016). The Economic Paradigm of Educational Globalization. Periodyc naukowy Academii Polonijnej, Czestochowa, Vol. 18, 3, 11-19. [in English].

Mamanazarov, A., Gushko, S., Kulishov, V. (2017). The paradigm of economic culture formation in the context of educational globalization. Mastery of a mentor. Scientificmethodical journal: Tashkent, No 1, 15-18. [in English].

OCDE/INITE. (2008). Educaciôn y sociedad. (Ed.). México: Fondo de Cultura Econömica. [in Spanish].

Pelaez, G. (1984). Historia del sindicato nacional de trabajadores de la educaciôn. (Ed.). México: Cultura Popular. [in Spanish].

Toh, Swee-Hin, and FIoresca-Cawagas, V. (2003). Globalization and the Philippines' Education System. Globalization and Educational Restructuring in the Asia Pacific Region, 189-231. [in English]. 